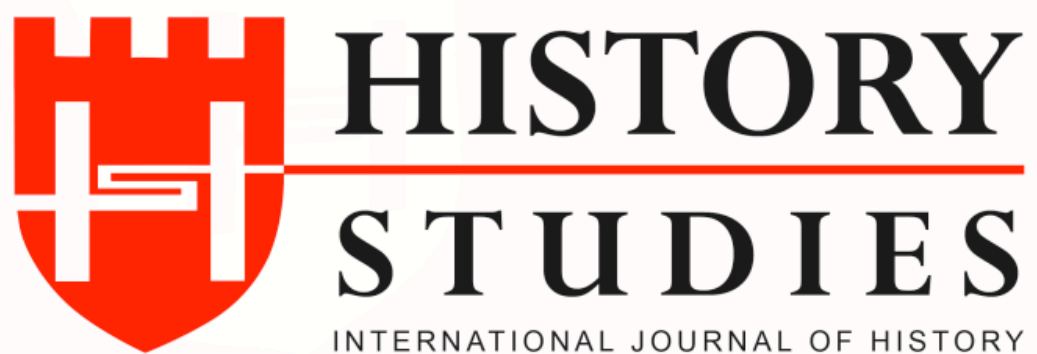

\author{
ISSN: 13094173 (Online) 1309 - 4688 (Print) \\ Volume 11 Issue 6, December 2019 \\ DOI Number: 10.9737/hist.2019.803 \\ Araştırma Makalesi \\ Makalenin Geliş Tarihi: 16.10.2019 Kabul Tarihi: 04.11.2019 \\ Atıf Künyesi: Mucize Ünlü - Ahmet Yadi, “Rewarding of The Ottoman Ulachs by Romania”, \\ History Studies, 11/6, Aralık 2019, s. 2125-2138.
}

\title{
REWARDING OF THE OTTOMAN ULACHS BY ROMANIA
}

\author{
Osmanlı Ulahlarinin Romanya Tarafindan Taltifi \\ Assoc. Prof. Dr. Mucize Ünlü - Ahmet Yadi \\ ORCID No: 0000-0002-8263-5602 / 0000-0002-0405-3535 \\ Ondokuz Mayıs University
}

\begin{abstract}
After gaining its independence in 1878, Romania was closely interested in the Ottoman Ulachs (Vlachs) and the Ulachs became a part of the Ottoman-Romanian diplomatic relations. Romania played an important role in the recognition of the Ulachs as a nation by the Ottoman Empire in 1905. In this period, some Ulachs of the Ottoman subjects, most of whom were active in the field of education, were awarded the orders (decorations) and medals. This study, which is based on the documents of the Ottoman Archives, deals with the Ulachs awarded by Romania.
\end{abstract}

Key Words: Ottoman Empire, Romania, Ulachs (Vlachs), Awarding, Medals.

Öz: Romanya, 1878 yılında bağımsızlığını kazandıktan sonra Osmanlı Ulahlarıyla yakından ilgilenmiş ve Ulahlar, Osmanlı-Romanya diplomatik ilişkilerinin bir parçası olmuştur. 1905 yılında Osmanlı Devleti tarafından Ulahların millet olarak tanınmasında Romanya önemli rol oynamıştır. Bu süreçte çoğu eğitim alanında faaliyet gösteren Osmanlı tebaasından bir kısım Ulah Romanya tarafından nişan ve madalyalar verilerek taltif edilmiştir. Osmanlı Arşivi vesikalarının esas alındığı bu çalışma taltif edilen Ulahları konu edinmektedir.

Anahtar Kelimeler: Osmanlı Devleti, Romanya, Ulahlar, Taltif, Madalya.

\section{Introduction}

The Principals of Wallachia and Bogdan, which are indicated as Memleketeyn ${ }^{1}$ in the Ottoman state records, merged in 1859 and formed the Romanian Principality, and this merger was registered in 1861 by the Sultan ${ }^{2}$. At the end of the Ottoman-Russian War of 1877-1878, the Principality of Romania was liberated from Turkish domination and it became fully independent with the Treaty of Berlin ${ }^{3}$. And also in 1879 it was recognized by the Ottoman Empire ${ }^{4}$.

\footnotetext{
${ }^{1}$ Cafer Çiftçi, "Bâb-1 Âlî’nin Avrupa’ya Çevrilmiş İki Gözü: Eflak ve Boğdan'da Fenerli Voyvodalar (1711-1821)”, Uluslararası İlişkiler, Volume 7, Number 26 (Summer 2010), p. 28; Kemal Karpat, "Eflak", Türkiye Diyanet Vakfi Íslam Ansiklopedisi, Volume 10, Istanbul 1994, p. 466.

${ }_{2}^{2}$ İrsel Abdula, Türkiye-Romanya Arasinda Göç ve Göçmen Meselesi (1878-1940), Ankara University, Institute of Social Sciences, Master Thesis, Ankara 2005, p. 15.

${ }^{3}$ Giray Saynur Bozkurt, "Geçmişten Günümüze Romanya'da Türk Varlığı”, Karadeniz Araştırmalarl, Volume 5, Number 17, Spring 2008, p. 3.

${ }^{4}$ Cezmi Karasu, "Bağımsızlıktan I. Dünya Savaşı’na Romanya”, Balkanlar El Kitabı, Volume I: History, Compilers: Osman Karatay-Bilgehan A. Gökdağ, Karam Araştırma ve Yayıncılık, Ankara 2006, p. 524; Mihai Maxim, “Romanya-Tarih", Türkiye Diyanet Vakfi Íslam Ansiklopedisi, Volume 35, Istanbul 2008, p. 170.
} 
Diplomatic contacts had been initiated in order to establish bilateral relations between the Ottoman Empire and Romania since September 1878. Dumitru Bratianu, the first ambassador sent to Istanbul by Romania, established Romania's first consulate in October 1878. Apart from Istanbul, there were Romanian consulates also in Thessaloniki, Adana and Izmir. On December 5,1878 , a treaty on the exchange of war prisoners was signed between the two states. On 15 December 1878, Süleyman Bey, the first ambassador of the Ottoman Empire, presented his credentials to Bucharest, and then the consulates of Iași (Yaş), Călărași and Tulcea (Tulçe), Constanta (Köstence), Giurgiu (Yergöğü), Turnu Severin, Brăila (İbrail), and Galaţi (Kalas) were established respectively in the dates of 1879, 1880, 1882, 1891, 1892, 1895 and 1897. Sultan Abdulhamid underlined the necessity of maintaining the relations between the two countries in a friendly manner in the dinner given in honour of Bratianu, the Ambassador of Romania ${ }^{5}$.

The Ottoman-Romanian bilateral relations which continued in the political and commercial fields until the end of the $19^{\text {th }}$ century gained a new momentum with the Consulate Agreement signed on August 10, 1900, and the Trade Agreement signed on August 12, 1901. Also, with the contribution of these good relations, the right of the Romanian government to the Macedonian Ulachs was registered in 1905 and the Ulachs in the region were given the right to use Romanian in churches and schools, and to elect representatives for local administrative authorities. In addition, a Romanian High School was decided to open in Skopje ${ }^{6}$ on behalf of the Romanian government ${ }^{7}$.

After gaining its independence, the willingness and approach of the Romanian government to make new connections by improving relations with Turkey could be seen also in the Ottoman side. In the article titled "La Turquie et la Roumanie" published in Malumat on May 20,1897 , the statements affirming the Romanian government were included and also it was stated that the Romanian government always adopted a conciliatory, calming and friendly attitude towards the Ottoman government. In another article published under the title "Le Gouvernement Impérial et la Roumanie" in the same magazine in July 1897, it was pointed out that Romania among the Balkan countries had the most advanced level of progress, wealth and the necessary conditions for good governance by including positive statements about kingdom of Carol I. Additionally, it was indicated that Turkey responded to this attitude in a friendly manner as Bucharest government maintained Turkey's friendship ${ }^{8}$.

As an indication of the satisfaction with the harmonious relations between the Ottoman Empire and Romania, the Bucharest authorities gave medals and decorations (orders) to the Ottoman diplomats and politicians visiting or passing through it. Munir Pasha ${ }^{9}$, the Minister of Protocol $^{10}$ of Sultan Abdulhamid, was one of them that he made his return from England in July

\footnotetext{
${ }^{5}$ Abdula, p. 18-19.

${ }^{6}$ It is called "Üsküp" in Turkish.

${ }^{7}$ Abdula, p. 20-21.

${ }^{8}$ Cecilia Alina Sava-Mihaela Mehedinti, "The Evolution of the Political and Diplomatic Relations Between Romania and the Ottoman Empire (1878-1912)", in Le Guerre Balcaniche e la fine del "Secolo Lungo". Atti del convegno di Târgu Mureş (19-20 luglio 2012), ed. Giuseppe Motta, Roma: Edizioni Nuova Cultura, 2013, pp. 79102.

${ }^{9}$ Munir Pasha was sent to England to attend the ceremony in order to celebrate the sixtieth anniversary of Queen Victoria on this date. Munir Pasha, who was also in the Paris Embassy, was employed under the rule of the Sultan in the palace due to his credibility and Sultan Abdulhamit II carried out his contacts with foreign ambassadors through Munir Pasha, leaving the Grand Vizier and his foreign minister aside. (Salih Münir Paşa [Çorlu], Geçmiş Zamanlar II. Abdülhamid Devri Osmanl Diplomasisi, Istanbul ve Paris Hatıralart, Prepared by Ali Birinci and Selma Günaydın, Türk Tarih Kurumu Yayınları, Ankara 2015, p. 374).

${ }^{10}$ It is called "Teşrifat Nazırı" who is an important official that implements the protocol works in Sublime Porte.
} 
1897 through Romania and returned to Istanbul after three days in Sinaia. Munir Pasha and his companions were rewarded by King Carol I during their stay in Sinaia ${ }^{11}$. There are also many examples from previous years regarding rewards given by Romania. In October 1887 Galip Pasha, the Governor of Thessaloniki, Halil Rifat Pasha, the Governor of Bitola ${ }^{12}$, Recep Pasha, General Commander of Thessaloniki ${ }^{13}$, Ragip Efendi, who was close to the Sultan, and also Filib Efendi, the concessionaire of Newspaper 'Tarik', were given the Order of the Couronne de Roumanie ${ }^{14}$ from the first rank; Asim Bey, Principal Clerk of Citizenship ${ }^{15}$, his deputy İstavraki Efendi, Yusuf Efendi, Policy Director of the Province of Thessaloniki, and Mayor Teyfik Bey were awarded the Order of the Couronne de Roumanie from the third rank. Deputy Consul General of Romania in Thessaloniki and Chief Dragoman of Embassy of Romania in Istanbul were assigned to deliver the decorations and certificates ${ }^{16}$ to their owners ${ }^{17}$.

The Romanian government continued to reward the Ottoman subjects also in the 1900s. In 1900 Vasaf Efendi, Director of Education of Bitola Province, and due to the effort to do his job well and his success in ensuring public order, Osman Bey, Chief Police Commissioner of Bitola Province, were given the Order of the Couronne de Roumanie ${ }^{18}$ from the fourth rank, and while Abdulkerim Pasha, the Governor of Bitola, was awarded the Order of the Esteiva Roumanie $^{19}$ from the first rank in 1901, Hasan Fehmi Pasha, the Governor of Thessaloniki, was given the Order of the Etual de Roumanie ${ }^{20}$ in $1902^{21}$. In addition, governors of Thessaloniki and Bitola, Nuri Efendi from Bitola, police officer of Thessaloniki province and Atıf Efendi, Foreign Document Control ${ }^{22}$ Officer of Selanik, were among those awarded by Romania between the dates of 1904 and $1905^{23}$.

In 1906 in the province of Bitola, Kostaki Aşkoderyano Efendi, member of Administrative Council $^{24}$, Sadık Vicdani Efendi, officer managing the editorial department ${ }^{25}$ of the province,

Volume 11

Issue 6

December

2019

${ }^{11}$ Sava- Mehedinti, p. 8-10.

${ }^{12}$ It is called "Manastır" in Turkish.

${ }^{13}$ It is called "Umum Kumandanı" in Turkish.

${ }^{14}$ Koron de Romani Nişanı (Courounne de Roumanie-Romanya Tacı) was created by King Charles (Carol I) on 10/22 May 1881. (Ülke Adlarına Göre Tasnif Edilmiş Madalya ve Nişanlar Hakkında Bilgi Fişleri, Atatürk Kitaplığı, Inventory: Bel_Mtf_58452,p. 21).

${ }^{15}$ It is called "Tâbiiyet Kalemi Müdürü" İn Turkish.

${ }^{16}$ It is called "berat" in Turkish that is the official paper written and issued by the state for orders, rank, civil service, salary and various privileges and powers.

${ }^{17}$ Ottoman Archives (BOA), Irade Hariciye (I.HR.) 308/19602, 13 Safer 1305/31 October 1887; Irade Dahiliye (I.DH.) 1060/83191, 22 Rebiülevvel 1305/8 December 1887.

${ }_{18}^{18}$ BOA, Irade Taltifat (İ.TAL.) 206/26, 6 Zilkade 1317/8 March 1900; Babıali Evrak Odasi (BEO.), 1454/1090431, 9 Zilkade 1317/11 March 1900; Dahiliye Nezareti Mektubi Kalemi (DH.MKT.) 2306/101, 26 Kanun-1 Sani 1315/7 February 1900, I.TAL. 208/24, 3 Zilhicce 1317/4 April 1900; BEO. 1473/110410, 16 Zilhicce 1317/17 April 1900.

19 BOA, I. TAL. 203/38, 23 Şevval 1317/24 February 1900; BEO. 1449/108616, 28 Şevval 1317/1 March 1900; DH.MKT. 2327/28, 19 Mart 1317/1 April 1901. (The names of the orders and medals have been read as written in Ottoman documents.).

${ }^{20}$ Etual de Romani Nişanı (Etoile de Roumanie-Romanya Y1ldızı) was created by Prince Charles (Carol I) in 1877. (Ülke Adlarına Göre Tasnif Edilmiş Madalya ve Nişanlar Hakkında Bilgi Fişleri, p. 21).

${ }^{21}$ BOA, I.TAL. 286/14, 21 Cemaziyelahir 1320/25 Semptember 1902; BEO. 1926/144450, 25 Cemaziyelahir 1320/29 September 1902.

${ }_{22}$ It is called "Muayene-i Kütüb ve Resail-i Ecnebiye" in Turkish.

${ }^{23}$ BOA, I.TAL. 352/49, 17 Şevval 1322/25 December 1904; BEO. 2501/187541, 30 Zilkade 1322/5 February 1905; I.TAL. 382/53, 16 Şevval 1323/14 February 1905; BEO.2722/204149, 19 Şevval 1323/17 December 1905; Dahiliye Nezareti Şifre Kalemi Belgeleri (DH.ŞFR.) 354/68, 11 Eylül 1321/24 September 1905; I.TAL. 382/55, 5 Şevval 1323/3 December 1905; BEO. 2714/203504, 6 Şevval 1323/4 December 1905; I.TAL. 333/17, 1 Rebiülevvel 1322/16 May 1904; BEO. 2347/176020, 22 Rebiülevvel 1322/6 June 1904; 2307/172973, 18 Muharrem 1322/4 April 1904.

${ }^{24}$ It is called "Meclis-i İdare" in Turkish.

${ }^{25}$ It is called "Mektupçu" in Turkish. 
Saib Efendi, Director of Education, and Yunus Şinasi Efendi, interpreter of the Province, were awarded by the Romanian State ${ }^{26}$. During the same year, many officers including officer of Romanian Embassy ${ }^{27}$, undersecretary of Foreign Affairs, District Governor on duty in Macedonia and Istanbul, and inspector, aide and manager working in various ministries were awarded with the decorations and medals of various ranks under the name of Etual de Roumanie, Couronne de Roumanie, Serviçyol Karadinyos Gold Medal, Serviçyol Karadinyos Silver Medal. Both Muslims and non-Muslims were among those who were awarded ${ }^{28}$. At the beginning of 1907, on the occasion of the fortieth anniversary of the Romanian King Carol I, the consulates of the Ottoman Empire in Romania were given medals ${ }^{29}$. Also, on September 30, 1907, the Romanian Government awarded 4 government officers ${ }^{30}, 1$ police commissioner and 16 employees of Sublime Porte, which includes 11 caretakers, servant, curtain maker, and janitor, the Medals of Gold Serviçyol Karadiniçyor from the first rank and Silver Serviçyol Karadiniçyor from the second rank ${ }^{31}$. In the same year, Zeynelabidin Efendi, the Director of Kırşova Sub-district in Bitola province, was given the Order of the Couronne de Roumanie from the fifth rank $^{32}$.

\section{The Ulachs Awarded by the Romania}

The Ulachs were also among the Ottoman subjects awarded by Romania. This nation having ethnic ties with Romania lived in various parts of the Balkans, especially in Macedonia. At the beginning of the $20^{\text {th }}$ century, their population in Macedonia was around 100 thousand ${ }^{33}$. The Ulachs, who are known by such names as the Vlachs, Valachs, Volochs and pastoral race, were mostly engaged in jobs that required a nomadic life. Those having better living conditions went to European countries such as Italy, Spain, Austria, and Russia in order to merchandise ${ }^{34}$. The Ulachs, who spoke Romance language and were Orthodox and connected to the Greek Patriarchate ${ }^{35}$ and also had many problems with the Greeks, were recognized by the Ottoman Empire in 1905 as a separate nation ${ }^{36}$. Especially after this date, many Ulachs from the Ottoman subjects, most of who were employed in the field of education, would be awarded with various degrees of decorations and medals by Romania.

\footnotetext{
${ }^{26}$ BOA, I.TAL. 405/8, 23 Receb 1324/12 September 1906; I.TAL. 428/29, 9 Cemaziyelevvel 1325/20 June 1907; BEO. 2909/218159, 27 Receb 1324/16 June 1906; I.TAL. 409/35, 10 Ramazan 1324/28 October 1906; DH.MKT. 1012/27-1, 7 Şevval 1323/5 December 1905; DH.MKT. 1114/70, 2 Receb 1324/22 August 1906; BOA, BEO. 2777/208240, 12 Muharrem 1324/8 March 1906; I.TAL. 389/37, 11 Muharrem 1324/7 March 1906; BEO. 3031/227277, 27 Safer 1325/11 April 1907.

${ }^{27}$ It is called "Romanya Sefareti Kavası" in Turkish.

${ }^{28}$ BOA, I.TAL. 389/37, 11 Muharrem 1324/7 March 1906; DH.MKT. 1084/63, 7 Rebiülevvel 1324/1 May 1906.

${ }^{29}$ BOA, I.TAL. 419/24, 26 Muharrem 1325/11 March 1907. One of those awarded the medal is Nesim Alacem who worked as a translator and cancelliere (officer in embassy secretariat) at the consulate of Turnu Severin in Romania of the Ottoman Empire. (Sezai Balc1-Ahmet Yadi, Osmanlı Bürokrasisinde Yahudiler, Libra Yayınları, Istanbul 2013, p. 163).

${ }^{30}$ It is called "Sadaret Ağası" in Turkish.

${ }^{31}$ BOA, I.TAL. 435/43, 17 Eylül 1323/30 September 1907.

32 BOA, I.TAL. 419/24, 14 Safer 1325/29 March 1907; BEO. 3117/233753, 26 Cemaziyelahir 1325/6 August 1907; DH.MKT. 1180/46, 26 Temmuz 1323/8 August 1907; I.TAL. 428/29, 24 Cemaziyelahir 1325/4 August 1907.

${ }_{33}$ Mustafa Alkan, "Hüseyin Hilmi Paşa'nın Rumeli Umumi Müfettişliği (1902-1908)", Celal Bayar University Sosyal Bilimler Dergisi, Volume 13, Number 1, March 2015, p. 246.

34 Iffet Tosun, "Ulahların-Romenlerin Ortaya Çıkıșı", Balkanlar El Kitabı, Volume I: History, Compilers: Osman Karatay-Bilgehan A. Gökdağ, Ankara 2006, p. 257; Lucy M.J. Garnett, Türkiye'nin Kadınlarl ve Folklorik Özellikleri, Oğlak Yayıncılık, Istanbul 2009, p. 17-18.

${ }^{35}$ Mehmet Köseoğlu, Başbakanlık Osmanlı Arşiv Belgelerine Göre Ulahların Siyasi, Dini ve Eğitim Faaliyetleri (1876-1910), Batman University-Frrat University (Joint Program) Institute of Social Sciences, Master Thesis, Elazığ 2015, p. 3.

${ }^{36}$ BOA, I.DH. 1434/10, 17 Rebiülevvel 1323/22 May 1905; Sava- Mehedinti, p. 10.
} 
In October 1905, the Romanian government gave decorations and medals to the directors, teachers and inspectors of the Ulach schools and some officers in the provinces of Bitola, Kosovo and Edirne and some people from the Ulach community and the clergy. Information about 29 people awarded on this date is given in the following table ${ }^{37}$.

The Ulachs Awarded by the Romanian Government

\begin{tabular}{|c|c|c|c|}
\hline Profession & Place & Name & $\begin{array}{c}\text { Decorations which was } \\
\text { given }\end{array}$ \\
\hline Doctor of Ulach Schools & Bitola & $\begin{array}{l}\text { Doctor Perikli } \\
\text { Poçara }\end{array}$ & $\begin{array}{l}\text { Order of the Couronne de } \\
\text { Roumanie from the Fifth } \\
\text { Rank }\end{array}$ \\
\hline $\begin{array}{l}\text { Headmaster of Bitola } \\
\text { Ulach School }\end{array}$ & Bitola & Kara Adam & $\begin{array}{l}\text { Order of the Couronne de } \\
\text { Roumanie from the Fifth } \\
\text { Rank }\end{array}$ \\
\hline $\begin{array}{l}\text { Member of Ulach } \\
\text { Community }\end{array}$ & Hârşova $^{38}$ & Petraşinko & $\begin{array}{c}\text { Order of the Couronne de } \\
\text { Roumanie from the Fifth } \\
\text { Rank }\end{array}$ \\
\hline $\begin{array}{l}\text { Member of Ulach } \\
\text { Community }\end{array}$ & Prilep $^{39}$ & Maçari & $\begin{array}{c}\text { Order of the Couronne de } \\
\text { Roumanie from the Fifth } \\
\text { Rank }\end{array}$ \\
\hline Ulach Art Teacher & Bitola & $\begin{array}{c}\text { Kostantin } \\
\text { Aşkoderyano }\end{array}$ & $\begin{array}{l}\text { Order of the Couronne de } \\
\text { Roumanie from the Fifth } \\
\text { Rank }\end{array}$ \\
\hline $\begin{array}{c}\text { Chamberlain }^{40} \text { of Bitola } \\
\text { Ulach School }\end{array}$ & Bitola & $\begin{array}{l}\text { Kostantin } \\
\text { Balamaci }\end{array}$ & $\begin{array}{c}\text { Serviçyo Karadiniçyor } \\
\text { Medal from the Fifth Rank }\end{array}$ \\
\hline $\begin{array}{l}\text { Headmaster of Ulach } \\
\text { School }\end{array}$ & Bitola & Filip Apostolisko & $\begin{array}{l}\text { Raspilat Muşci Medal } \\
\text { from the First Rank }\end{array}$ \\
\hline $\begin{array}{c}\text { Former Teacher of Ulach } \\
\text { School }\end{array}$ & Bitola & $\begin{array}{l}\text { Haci Dimitri } \\
\text { Atnaşeşko }\end{array}$ & $\begin{array}{l}\text { Raspilat Musci Medal } \\
\text { from the First Rank }\end{array}$ \\
\hline $\begin{array}{c}\text { Headmaster of Ulach } \\
\text { School }\end{array}$ & Udala & $\begin{array}{l}\text { Yvan Tomesko } \\
\text { Somo }\end{array}$ & $\begin{array}{l}\text { Raspilat Musci Medal } \\
\text { from the First Rank }\end{array}$ \\
\hline $\begin{array}{l}\text { Inspector of Ulach } \\
\text { Schools }\end{array}$ & Bitola & Sonderozon & $\begin{array}{l}\text { Raspilat Musci Medal } \\
\text { from the First Rank }\end{array}$ \\
\hline $\begin{array}{l}\text { Headmistress of Ulach } \\
\text { School for Girls }\end{array}$ & Bitola & Eleni Toka & $\begin{array}{l}\text { Raspilat Musci Medal } \\
\text { from the Second Rank }\end{array}$ \\
\hline $\begin{array}{c}\text { Former Teacher of Ulach } \\
\text { School }\end{array}$ & Bitola & Perdiki & $\begin{array}{l}\text { Raspilat Musci Medal } \\
\text { from the Second Rank }\end{array}$ \\
\hline Headmaster & $\begin{array}{c}\text { Veliko } \\
\text { Tarnovo }^{41}\end{array}$ & $\begin{array}{c}\text { Dimitri } \\
\text { Nikolesko }\end{array}$ & $\begin{array}{l}\text { Raspilat Musci Medal } \\
\text { from the Second Rank }\end{array}$ \\
\hline
\end{tabular}

\footnotetext{
${ }^{37}$ BOA, I.TAL. 378/43, 19 Şaban 1323/19 October 1905; BEO. 2692/201853, 22 Şaban 1323/22 October 1905; DH.MKT. 1029/39, 1 Ramazan 1323/30 October 1905.

${ }^{38}$ It is also spelled Hîrșova.

${ }^{39}$ Pirlepe.

${ }^{40} \mathrm{He}$ is a trusted person who deals with the administrative work of the institutions.

${ }^{41}$ Tirnova.
} 
Rewarding of The Ottoman Ulachs by Romania

\begin{tabular}{|c|c|c|c|}
\hline Headmaster & Nedeşka & Yonesko Kirane & $\begin{array}{l}\text { Raspilat Musci Medal } \\
\text { from the Second Rank }\end{array}$ \\
\hline Headmaster & Malovişte $^{42}$ & Dimitri Zografo & $\begin{array}{l}\text { Raspilat Musci Medal } \\
\text { from the Second Rank }\end{array}$ \\
\hline Headmaster & Nedeşka & $\begin{array}{c}\text { Sergey } \\
\text { Dimitrisko }\end{array}$ & $\begin{array}{l}\text { Raspilat Musci Medal } \\
\text { from the Second Rank }\end{array}$ \\
\hline Headmaster & Skopje & Kika Papa & $\begin{array}{l}\text { Raspilat Musci Medal } \\
\text { from the Second Rank }\end{array}$ \\
\hline Headmaster & Hârşova & Taşko Elbasko & $\begin{array}{l}\text { Raspilat Musci Medal } \\
\text { from the Second Rank }\end{array}$ \\
\hline School Teacher & Hârşova & Vangeli Petresko & $\begin{array}{l}\text { Raspilat Musci Medal } \\
\text { from the Second Rank }\end{array}$ \\
\hline Headmaster & Glisora & Kika Papa & $\begin{array}{l}\text { Raspilat Musci Medal } \\
\text { from the Second Rank }\end{array}$ \\
\hline School Teacher & Glisora & Adam & $\begin{array}{l}\text { Raspilat Musci Medal } \\
\text { from the Second Rank }\end{array}$ \\
\hline Headmaster & Toricse & Dimitri Çima & $\begin{array}{l}\text { Raspilat Musci Medal } \\
\text { from the Second Rank }\end{array}$ \\
\hline Inspector of School & Bitola & Dimitri Ran & $\begin{array}{l}\text { Raspilat Musci Medal } \\
\text { from the Second Rank }\end{array}$ \\
\hline Priest & Peridosi & Kostanisko & $\begin{array}{l}\text { Raspilat Musci Medal } \\
\text { from the Second Rank }\end{array}$ \\
\hline Priest & Gopeş & Hristolov & $\begin{array}{l}\text { Raspilat Musci Medal } \\
\text { from the Second Rank }\end{array}$ \\
\hline Priest & Hârşova & Sutri Esteriyo & $\begin{array}{l}\text { Raspilat Musci Medal } \\
\text { from the Second Rank }\end{array}$ \\
\hline Priest & Ohrid $^{43}$ & $\begin{array}{l}\text { Vançibo } \\
\text { Bornoçibo }\end{array}$ & $\begin{array}{l}\text { Raspilat Musci Medal } \\
\text { from the Second Rank }\end{array}$ \\
\hline Priest & Orestiada $^{44}$ & Anami Esteriyo & $\begin{array}{l}\text { Raspilat Musci Medal } \\
\text { from the Second Rank }\end{array}$ \\
\hline Headmaster & Hârşova & $\begin{array}{c}\text { Kostas } \\
\text { Askoderyano }\end{array}$ & $\begin{array}{l}\text { Raspilat Musci Medal } \\
\text { from the Second Rank }\end{array}$ \\
\hline
\end{tabular}

As can be seen from the table, 21 of the awarded 29 people were working in educational institutions. 13 of them are headmasters, 5 of them are teachers, 2 of them are inspectors and 1 of them is doctor. 5 of the remaining 8 people are clergymen, 2 of them are members and 1 of them is chamberlain. Most of the awarded Ulachs are from the province of Bitola. One of the

\footnotetext{
${ }^{42}$ Molovişte.

${ }^{43}$ Ohri.

${ }^{44}$ Horpeşte.
} 
headmasters awarded a medal is a woman and she is Eleni Toka, Headmistress of Ulach School for Girls. Awarding for women in the Ottoman Empire took place during the reign of Abdulhamid II. This award, which was granted with the name of "The Order of Charity", consisted of three ranks according to the regulation dated 16 July 1878 . It would be given to women who served during wartime and in events such as earthquakes, fires and floods ${ }^{45}$. Besides, an amendment was made in 1905 in the regulation of the Merit Medal given in 1891 during the reign of Sultan Abdulhamit and women were also included in the list of those who could be awarded a medal ${ }^{46}$.

Ulach educational employees who were rewarded by the Romanian administration are not limited to those given in the table. In the same year, Perikli Çeboyka Efendi, the headmaster of Ulach School of Ioannina, was awarded the Order of Kavaler Couronne de Roumanie by the Romanian State due to his good work ${ }^{47}$. Gorgi Çonga from Ottoman subjects, who had been an inspector of Ulach schools for a while, was also awarded Pravora Karadinca Medal by the Romanian government for his good service ${ }^{48}$.

Upon the proposal of member of the Heyet-i Ayan in 1906, the Romanian government decided to issue medals reminiscent of the date of the decision of Koço Ulachs living in Vilayat-1 Selasede (Thessaloniki, Bitola, Kosovo) as a separate nation. Silver and bronze medals would be distributed to the people. While the pictures of the King of Romania, Prince Ferdinand, Prince Carol and Prince Nikola are on the front of the medal, Lahovary, Romanian Ambassador to Istanbul, who played an important role in the successful conclusion of the negotiations on this issue, is behind the medal. The bronze medal was valued at 8 francs and the silver ones at 100 francs. The income from the sale of the medals would be distributed to the Ulach families in need. On January 20, 1906, an article dealing with this issue was published in the newspaper La Romani ${ }^{49}$. In 1907, 7 people from the Ottoman subjects in the Kırşova sub-district of the province of the Bitola were granted Serviçyo Kradiçyoz Medal from the first rank by the Romanian government. They were Pope Esteri, Petro Balyo, Nikola Gogo, Dimitri Patraşinko, Taşko Elyasko, Vangeli Petraşko and Nikola Dimitri from the members of the Ulach community of Kırşova ${ }^{50}$. Before 1905, there were also those being Ulachs rewarded by the Romanian administration. Apostol Efendi, who would be appointed as the Istanbul Police Commissioner in the following years, was one of them. He was awarded the Medal of Service Fidel on December 16, 1892 and the Order of Couronne de Roumanie from the fifth rank on October $9,1903^{51}$.

\section{Conclusion}

All autocratic administrations of the $19^{\text {th }}$ century benefited from the symbolic value of medals and orders in their relations with both their subjects and diplomatic circles and these

\footnotetext{
45 İbrahim Artuk,"Nişan", Türkiye Diyanet Vakfi İslam Ansiklopedisi, Volume 33, Istanbul 2007, p. 155. With the Order of Charity, this symbol of power was no longer left to men and a privileged class and the middle class Ottoman woman was allowed to enter this area. (Melike Karabacak, "İktidarın Dişil Sembolleri Şefkat Nişanı Üzerine Bir Değerlendirme", Sultan II. Abdülhamid ve Dönemi Uluslararası Sempozyumu, 22-24 October 2018).

${ }^{46}$ Edhem Eldem, Iftihar ve Imtiyaz Osmanlı Nişan ve Madalyaları Tarihi, Osmanlı Bankası Arşiv ve Araştırma Merkezi, Istanbul 2004, p. 290.

${ }^{47}$ BOA, Maarif Nezareti Mektubi Kalemi (MF.MKT.) 825/11, 9 Kanun-1 Sani 1320/22 January 1905; I.TAL. 359/32, 16 Zilhicce 1322/21 February 1905; BEO. 2666/199937, 11 Receb 1323/11 September 1905.

${ }^{48}$ BOA, DH.MKT. 1124/7, 25 Şaban 1324/14 October 1906; İ.TAL.410/82, 5 Şevval 1324/21 November 1906; BEO., 2948/221063, 8 Şevval 324/25 November 1906.

${ }^{49}$ BOA, Ylldız Sadaret Hususi Maruzat Evrakl (YA-HUS.) 500/48, 10 Muharrem 1324/6 March 1906.

${ }^{50}$ BOA, I.TAL. 419/22, 24 Safer 1325/8 Nisan 1907.

${ }^{51}$ Mucize Ünlü-Ahmet Yadi, “II. Abdülhamid Döneminde Ulahların İstihdamına Dair”, History Studies, Volume 10, Number 10, December 2018, p. 276.
} 
tools were seen as an element of dialogue ${ }^{52}$. The Western-inspired medal tradition began in the Ottoman Empire during the reign of Mahmut II, and military and civil senior officers who did their duties in a superior manner were rewarded. Previously, successful people were presented with crest $^{53}$, wreath and chandelier in a similar manner to the order. The first order in the Western style was the Mecidî Order in 1852 and this tradition was continued during the reign of the later sultans and new medals and orders were produced. Especially during the reign of Sultan Abdulhamit, Ottoman medals and orders reached the level of institutionalization and systematization $^{54}$. In Romania, which was an independent state in 1878 , Prince Carol wanted to establish his own engagement from the 1860s and made efforts in this direction. In Romania, which was an independent state in 1878, Prince Carol wanted to create his own decorations from the 1860s and made efforts in this direction. He gained this sovereignty with the appearance of the Order of the Romanian Star in 1877 and the Order of the Crown of Romania in $1881^{55}$. While Sultan Abdulhamid was awarded the Order of the Romanian Star in 1880 and the Order of Carol I in 1907 by Romania, Carol I would be rewarded the Order of Tasvir-i Humayun in 1866 and the Mecidî Order in 1907 by the Ottoman Empire. In addition, Queen Elizabeth was awarded the Concession Medal in the dates of 1893 and 1907, and the Order of the Dynasty in $1907^{56}$. Except for these mutual awarding at the level of heads of state, the governments of the two countries contributed to the development of bilateral relations by presenting orders and medals to each other's subjects on various occasions. An important part of the Ottoman citizens rewarded by the Romanian State were the Ulachs who had historical, cultural and ethnic ties with them. Thus, Romania both developed good relations with the Ottoman administration and also expressed its support to the Ulachs.

\section{REFERENCES}

\section{Ottoman Archives}

Babıâli Evrak Odası (BEO.)

Dahiliye Nezareti Mektubi Kalemi (DH.MKT.)

Dahiliye Nezareti Şifre Kalemi Belgeleri (DH.ŞFR.)

İrade Dâhiliye (İ.DH.)

İrade Hariciye (İ.HR.)

İrade Taltifat (İ.TAL.)

Maarif Nezareti Mektubi Kalemi (MF.MKT.)

Yıldız Sadaret Hususi Maruzat Evrakı (Y.A.HUS.)

\section{Published and Unpublished Works - Articles}

ABDULA, İrsel, Türkiye-Romanya Arasında Göç ve Göçmen Meselesi (1878-1940), Ankara University, Institute of Social Sciences, Master Thesis, Ankara 2005.

\footnotetext{
${ }^{52}$ Namık Sinan Turan, "II. Abdülhamid Döneminde Diplomaside Sembolik Dil İnşasında Nişanın Yeri: Toplumsal Anlamda Ötekini Taltif Etmek 'Şefkat Nişanı'”, Halil İnalcık Armağanı III, editor: Ahmet Özcan, Doğu Batı Yayınları, Istanbul 2017, p. 218.

${ }_{53}$ It is an ornament which is feather-shaped made from feathers or animal hair, on the top of a soldier's hat.

${ }^{54}$ Artuk, p. 154-155; Eldem, p. 290, 357.

${ }^{55}$ Eldem, p. 356.

${ }^{56}$ Eldem, p. 502-505.
} 
ALKAN, Mustafa, "Hüseyin Hilmi Paşa'nın Rumeli Umumi Müfettişliği (1902-1908)”, Celal Bayar University Sosyal Bilimler Dergisi, Volume 13, Number 1, March 2015, pp. 242245.

ARTUK, İbrahim, "Nişan”, Türkiye Diyanet Vakfi İslam Ansiklopedisi, Volume 33, Istanbul 2007, pp. 154-156.

BALCI, Sezai - Ahmet Yadi, Osmanlı Bürokrasisinde Yahudiler, Libra Yayınları, Istanbul 2013.

BOZKURT, Giray Saynur, “Geçmişten Günümüze Romanya'da Türk Varlığı”, Karadeniz Araştırmaları, Volume 5, Number 17, Spring 2008, pp. 1-31.

ÇİFTÇİ, Cafer, "Bâb-1 Âlî’nin Avrupa'ya Çevrilmiş İki Gözü: Eflak ve Boğdan'da Fenerli Voyvodalar (1711-1821)", Uluslararası İlişkiler, Volume 7, Number 26 (Summer 2010), pp. 27-48.

ELDEM, Edhem, Iftihar ve Imtiyaz Osmanlı Nişan ve Madalyaları Tarihi, Osmanlı Bankası Arşiv ve Araştırma Merkezi, Istanbul 2004.

GARNETT, Lucy M.J., Türkiye'nin Kadınları ve Folklorik Özellikleri, Oğlak Yayıncılık, Istanbul 2009.

KARABACAK, Melike "İktidarın Dişil Sembolleri Şefkat Nişanı Üzerine Bir Değerlendirme”, Sultan II. Abdülhamid ve Dönemi Uluslararası Sempozyumu, 22-24 October 2018.

KARASU, Cezmi, "Bağımsızlıktan I. Dünya Savaşı'na Romanya”, Balkanlar El Kitabl, Volume I: History, Compilers: Osman Karatay-Bilgehan A. Gökdağ, Karam Araştırma ve Yayıncilık, Ankara 2006, pp.515-527.

KARPAT, Kemal, "Eflak", Türkiye Diyanet Vakfi İslam Ansiklopedisi, Volume 10, Istanbul 1994, pp. 466-469.

KÖSEOĞLU, Mehmet, Başbakanlık Osmanlı Arşiv Belgelerine Göre Ulahların Siyasi, Dini ve Eğitim Faaliyetleri (1876-1910), Batman University-Firat University (Joint Program) Institute of Social Sciences, Master Thesis, Elazığ 2015.

MAXIM, Mihai, "Romanya-Tarih", Türkiye Diyanet Vakfi İslam Ansiklopedisi, Volume 35, Istanbul 2008, pp.168-172.

Salih Münir Paşa [Çorlu], Geçmiş Zamanlar II. Abdülhamid Devri Osmanlı Diplomasisi, Istanbul ve Paris Hattralarl, Prepared by Ali Birinci and Selma Günaydın, Türk Tarih Kurumu Yayınları, Ankara 2015.

SAVA, Cecilia Alina - Mihaela Mehedinti "The Evolution of the Political and Diplomatic Relations Between Romania and the Ottoman Empire (1878-1912"), in Le Guerre Balcaniche e la fine del "Secolo Lungo". Atti del convegno di Târgu Mureş (19-20 luglio 2012), ed. Giuseppe Motta, Roma: Edizioni Nuova Cultura, 2013, pp. 79-102.

STANESCU, Adrian and Vlad, Laurentiu, (Compilers), Memorialistica Diplomatica Volume 1 Alexandru Em. Lahovary Amintiri Diplomatice Constantinopol (1902-1906). Viena (1906-1908), İnstitutul European 2009.

TOSUN, İffet, "Ulahların-Romenlerin Ortaya Çıkışı”, Balkanlar El Kitabı, Volume I: History, Compilers: Osman Karatay-Bilgehan A. Gökdağ, Ankara 2006, pp. 252-259. 
TURAN, Namık Sinan, "II. Abdülhamid Döneminde Diplomaside Sembolik Dil İnşasında Nişanın Yeri: Toplumsal Anlamda Ötekini Taltif Etmek 'Şefkat Nişanı”, Halil Inalcık Armağanı III, editor Ahmet Özcan, Doğu Batı Yayınları, Istanbul 2017, pp. 216-245.

Ülke Adlarına Göre Tasnif Edilmişs Madalya ve Nişanlar Hakkında Bilgi Fişleri, Atatürk Kitaplığ1, Inventory: Bel_Mtf_58452.

ÜNLÜ, Mucize - Ahmet Yadi, "II. Abdülhamid Döneminde Ulahların İstihdamına Dair", History Studies, Volume 10, Number 10, December 2018, pp. 267-282.

\section{Internet Sources}

http://www.damienlibert.com/html/fiche.jsp?id=697597\&np=8\&lng=fr\&npp=50\&ordre=3\&aff $=1 \& \mathrm{r}=(05.09 .2019)$

https://gallica.bnf.fr/ark:/12148/btv1b69316002.r=Carol\%20de\%20Roumanie?rk=64378;0 $(05.09 .2019)$

https://veryimportantlot.com/fr/lot/view/roumanie-ordre-de-la-couronne-de-roumanie-1-mo$\underline{110737}(05.09 .2019)$ 


\section{ATTACHMENTS}

Attachment-1: Couronne de Roumanie, 1. Modèle (1881-1932)
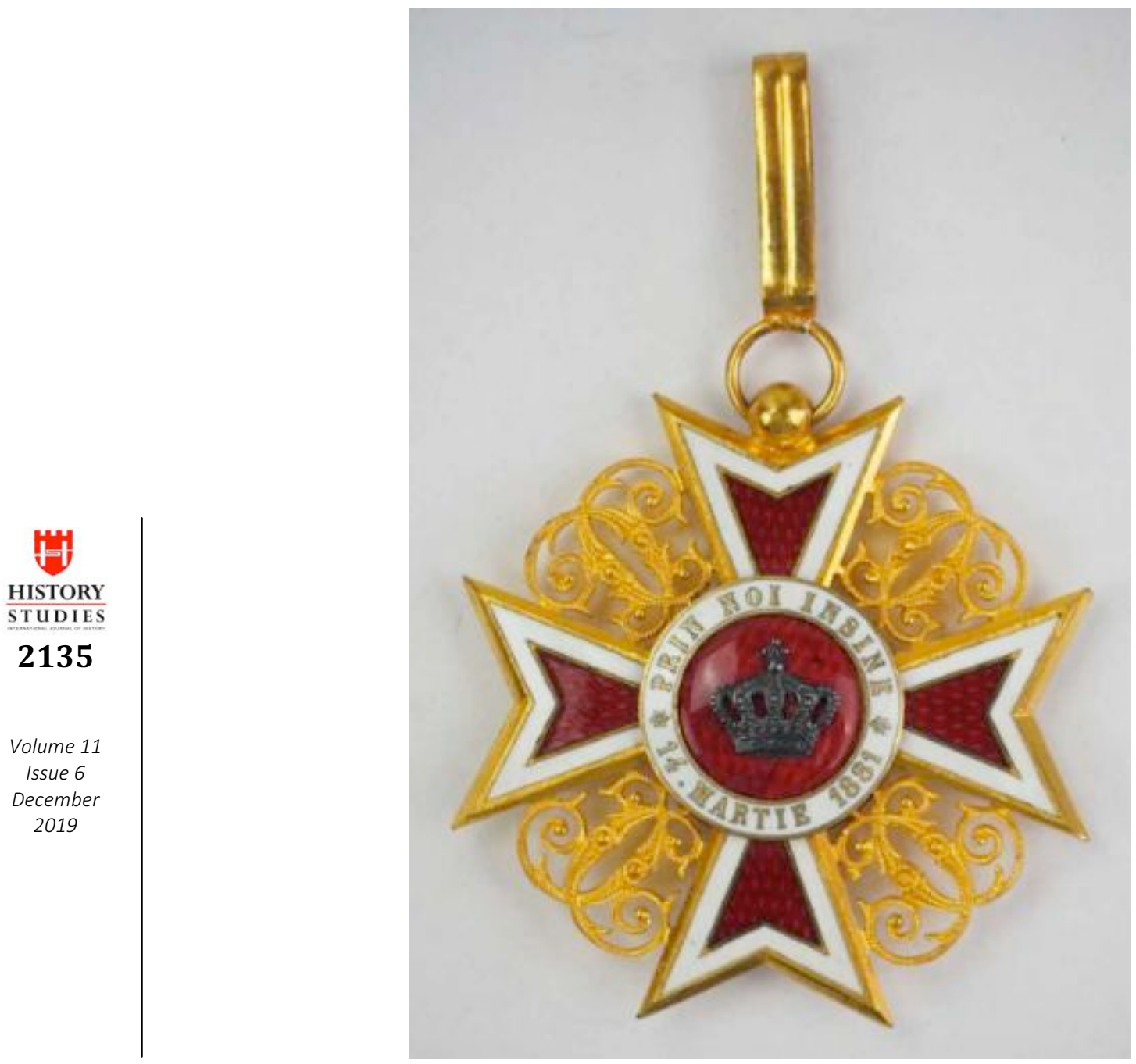

(Source:https://veryimportantlot.com/fr/lot/view/roumanie-ordre-de-la-couronne-deroumanie-1-mo-110737 Date of Access: 05.09.2019) 
Attachment-2: Couronne de Roumanie (1881)
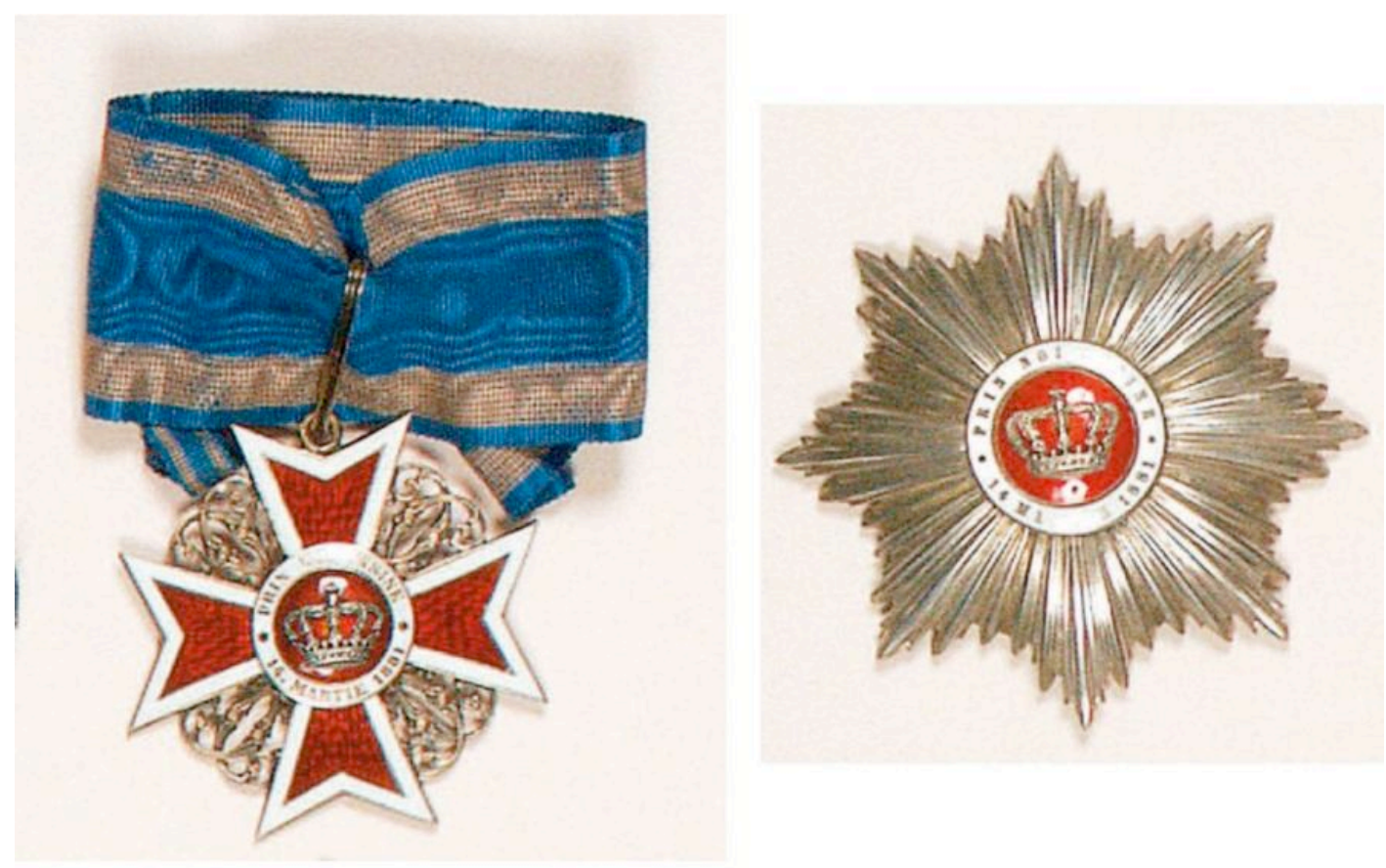

(Source:http://www.damienlibert.com/html/fiche.jsp?id=697597\&np=8\&lng=fr\&npp=50\&o

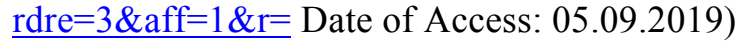


Attachment-3: King Carol I of Romania

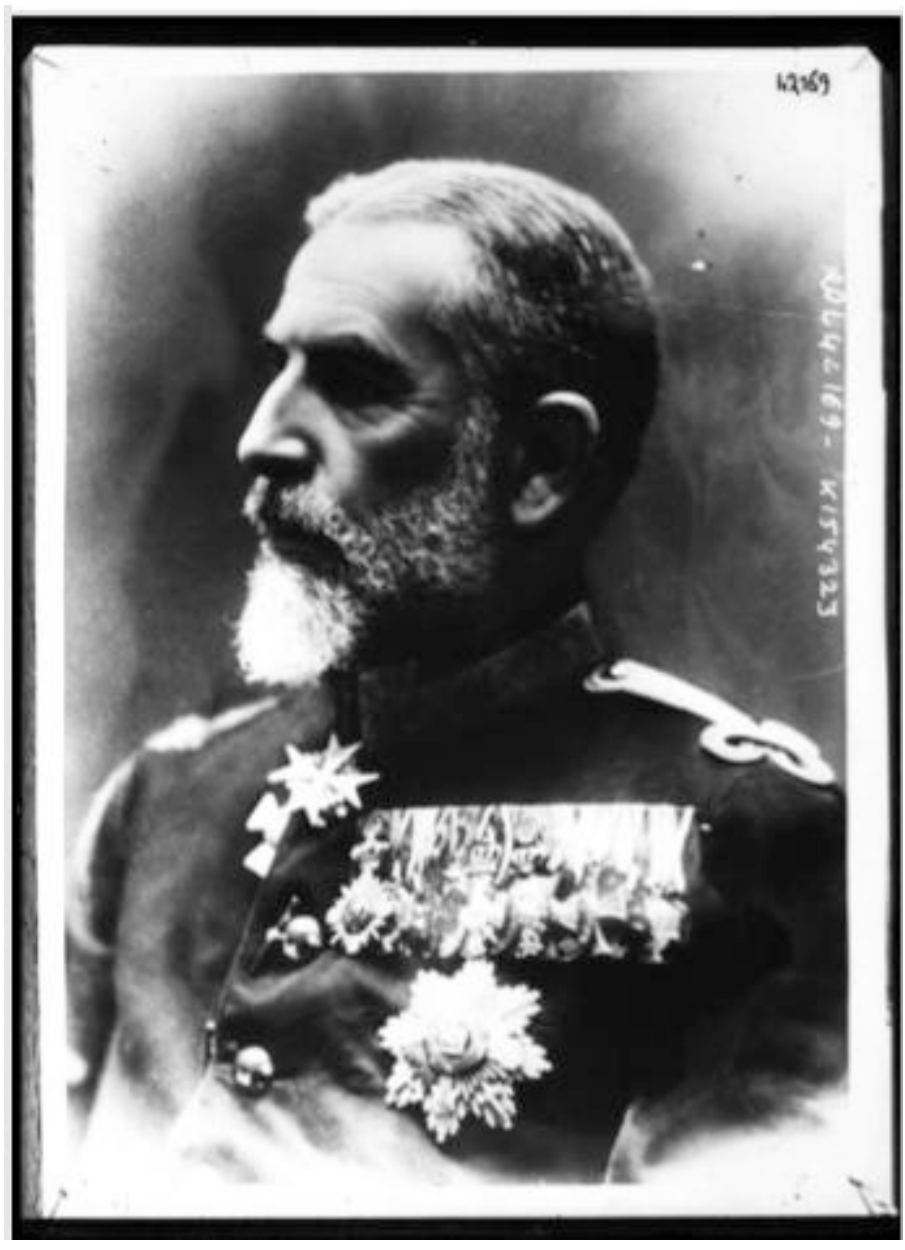

(Saource:Gallica,https://gallica.bnf.fr/ark:/12148/btv1b69316002.r=Carol\%20de\%20Rouma nie?rk $=64378 ; 0$ Date of Access: 07.09.2019) 
Attachment-4: Alexandru Em. Lahovary

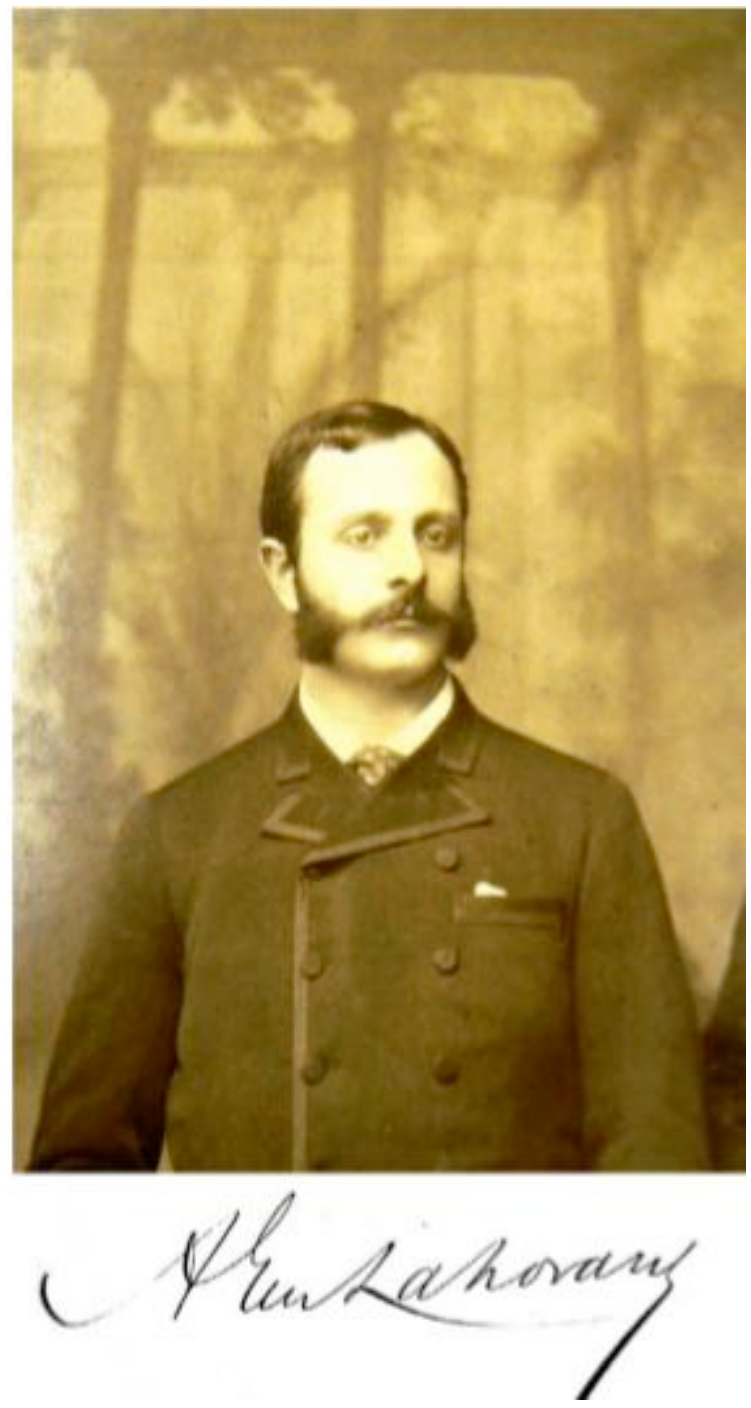

HISTORY STUDIES

(Source: Adrian Stanescu ve Laurentiu Vlad (Compilers), Memorialistica Diplomatica Vol.1 Alexandru Em. Lahovary Amintiri Diplomatice Constantinopol (1902-1906). Viena (19061908), İnstitutul European 2009, p. 5.) 